\section{A state in denial: Britain's WMD dependency on the United States}

\section{Dan Plesch}

$\mathrm{T}$

his study details the United Kingdom's unique dependence on the United States for supplying and using weapons of mass destruction (WMD), and its importance in modern politics. The Defence Committee of the House of Commons, the lower house of the British parliament reported that "it will also be essential to decide what level of dependence upon the United States the U.K. is willing to accept in any possible Trident successor. We must consider the potential policy implications of any technical dependencies upon the U.S. and the differing concepts of independence adopted by the U.K. and France." It added that "he public debate over the future of the U.K.'s strategic nuclear deterrent should address: the independence of the U.K.'s current system; and the operational and diplomatic impact of any potential dependency on the United States of any future U.K. nuclear deterrent." As the pro-nuclear Member of Parliament Julian Lewis put it, "Britain's ability to continue with nuclear weapons without U.S. support becomes very slim to the point of invisibility."

The Committee highlighted Colin Gray's evidence that "for anyone who wishes to question the true independence of the British nuclear deterrent I would concede that it is ... a hostage to American goodwill ... the dependency is critical and will continue." Interestingly, Colin Gray is doyen of the self-styled realist school of international relations theorists for whom the concept of "goodwill" has no influence on the actions of states. If goodwill is an illusion in affairs of state, to what is the United Kingdom hostage? As Chris Bellamy writes: "the British deterrent is probably the least independent of any ... could this be one reason why Prime Minister Tony Blair has been at such pains to support U.S. foreign and strategic policy over the past eight years?"3

This article traces the underlying economic constraints that have driven U.K. policymakers to continuous dependence upon the United States. It argues that the political and media elite, along with a large part of the strategic studies community are in denial over the reduced day-to-day independence of policy in the United Kingdom resulting from this relationship. And the system itself is entirely vulnerable to U.S. policy should Britain ever decide it needs to use its "deterrent." An understanding of the nature of the dependence makes other discussions concerning the need or not for a Trident successor at best irrelevant and, at worst, a collusion in a confidence trick on the electorate.

The article first discusses the history of American support for U.K. weapons of mass destruction and then examines the present state of dependence with respect to the Trident system before concluding that the United Kingdom in fact has no nuclear weapons option other than dependence on the United States.

The weapons in question were fitted to Royal Air Force bombers and ballistic missiles fired from Royal Navy submarines. In addition, and outside the scope of this study, the British Army trained to fire American atomic artillery shells and short-range surface-tosurface missiles from its artillery.

The point of an independent military force is to underpin national sovereignty and the ability to support the power of a nation-state. In contrast to other states with nuclear weapons and comparable or smaller industrialized economies, the United Kingdom has a very weak independent defense industrial base on which to build China, France, and Russia build their own weapons and delivery systems using largely or entirely independent industrial capacity created over half a century. India, Pakistan, and Israel have, as far as can be determined given the secrecy surrounding these states' programs, delivery systems of regional range, and small numbers of warheads all using a considerable degree of imported technology.

Were the United Kingdom to withdraw from the nuclear Mutual Defense Agreement with the United States, existing technology and corporate engagement would be withdrawn by the U.S. and U.S. companies. The U.K. would then need to develop the skills, technologies, and production capacity that it has time and again decided it either could not create itself or to which it chose not to devote the needed resources. Even if the political will existed in the British people to create a force comparable to the force to frappe, it is far from certain that the United Kingdom has a sufficient skill and technology base to create modern weapons and delivery systems. The creation of an Hiroshima-type atomic bomb to be dropped from aircraft is possibly practical - however, successive governments have determined since the late 1950 s that such a system is too vulnerable to preemptive attack and also lacks range and survivability against anti-aircraft weapons. Also, the United Kingdom has no independent long-range ballistic or cruise missile industrial capacity. For these reasons, almost regardless of financial commitment, an independent U.K. nuclear weapons industrial base in the twenty-first century appears to be impractical.

The origins of American support for Britain's nuclear force

British dependence on the United States for nuclear weapons started in the Second 
World War. This history shows that it is incorrect to think that the United Kingdom was ever an independent nuclear state like France, Russia, or China.

In 1940, Churchill initiated work on a British atomic bomb, rejecting a suggestion of cooperation from the U.S. President, Franklin Roosevelt, in October $1941 .^{4} \mathrm{He}$ soon realized that Britain did not have the resources to go it alone and sought to get involved with the United States, but it was not until the 1943 Quebec Agreement that Britain joined the Manhattan project that built the Hiroshima and Nagasaki bombs.

The official historian of Britain's nuclear weapons explains that "Britain had then become only a junior partner in the business, contributing significantly in various ways but present largely on American sufferance." In 1946, the U.S. Congress passed the MacMahan Act to stop nuclear collaboration with any state. British scientists returned home with information on how to build an atom bomb but without detailed knowledge of the industrial production processes.

Despite the MacMahan Act, some nuclear sharing quickly restarted, as the United States needed supplies of British-controlled uranium ore from the Congo. ${ }^{6}$ Until 1952 , the United States intermittently provided the United Kingdom with nine categories of information mostly on the construction of nuclear reactors for making nuclear explosives. ${ }^{7}$ Congressional leaders brought into the negotiations then threatened to withdraw the Marshall Plan aid program to get the Attlee government to give up joint control over the use of nuclear weapons agreed by Churchill and Roosevelt during the war. ${ }^{8}$

In 1947, the British atomic bomb project was restarted by the Labor government. In one account, it was the Foreign Secretary Ernest Bevin's intervention that swung the discussion among ministers. ${ }^{9}$ And the need to have a Union Jack on top of the bomb, in Bevin's famous phrase, was driven by the humiliating way that Bevin had just been spoken to by the U.S. Secretary of State, James Byrnes. The program was mentioned in Parliament in 1948, with more detail only provided shortly before the first British atomic test in 1952 under Winston Churchill's premiership. ${ }^{10}$ Churchill privately expressed surprise at how much money and work had been done in secret by the Labor government.

One of Churchill's last political acts was to try to reach out to the Sovie leadership after the death of Stalin in order to control the hydrogen bomb. He found he had no influence in Washington and, shortly before retiring, Churchill began the U.K. hydrogen bomb program, while privately expressing greater concern over the future of the world than he had even in 1940

Despite the great effort to produce the atomic bomb and jet bombers to carry them, the advanced development of next-generation technology, hydrogen bombs, and ballistic missiles, by both the United States and Russia in the 1950 s made it politically impossible for the United Kingdom to afford an independent nuclear weapons system.

In 1957, with great difficulty and expense, the United Kingdom exploded its first hydrogen bomb and, shortly thereafter, the United States agreed to provide full support for the British nuclear weapons program. As both Lorna Arnold and Peter
Hennessy describe in their studies of the British hydrogen bomb program, the key purpose in the mind of the Prime Minister, Harold Macmillan, was to show the Americans that the British were important enough a nuclear power to help, rather than to have an independent weapon.

In 1958, the U.S.-U.K. Mutual Defense Agreement (MDA) was signed, although very little was known about it in public. It has been renewed periodically ever since, the last time in 2004. The MDA allows the United States to provide the United Kingdom with nuclear weapons designs, nuclear weapons manufacturing, and nuclear reactor technology, designs, and materials.

A secret British government assessment of called "The Dangers of Becoming an American Satellite," only released after 1988, stated:

The U.K., in its relatively weak position, is already greatly dependent upon United States support. It would be surprising if the United States did not exact a price for the support, and to some extent it does so ... the more we rely upon them, the more we shall be hurt if they withhold it. ${ }^{11}$

Both governments have taken a highly secretive approach to nuclear weapons policies and programs throughout the years, and in the United Kingdom there is no academic center devoted to the study of the most important military relationship for the United Kingdom. Nevertheless, sufficient evidence exists to demonstrate clearly that from the beginning Britain has had a dependent relationship upon the United States and that this relationship has required strategic support for the United States in return for support for a U.K.-flagged nuclear weapon. In all the main aspects of nuclear weapons - explosive materials, warhead design and construction, and missiles - the United Kingdom has no independence.

Nuclear explosive materials

During the Cold War, tons of uranium and plutonium were traded between the two countries, and flatly denied at the time. In 1997, the Clinton administration revealed the extent of this exchange. Ross Hesketh wrote that the 5.4 tons of plutonium sent to the United States amounted to "the entire production of plutonium from all the U.K civil nuclear power stations, up to April 1969, according to official sources." ${ }^{12}$ This trade was helpful to the Americans, but vital to the British nuclear weapons program.

Today, renewed British interest in nuclear energy should be examined closely for any commercial, political, or technical connection to nuclear weapons. How, for example, can the British government be serious about being a nuclear weapons power if it is not going to have a modern nuclear industry? 


\section{Table 1: U.S./U.K. Joint Working Groups}

$$
\text { Group \# Title }
$$

$\begin{array}{ll}6 & \text { Radiation Simulation and Kinetic Effects } \\ 9 & \text { Energetic Materials } \\ 22 & \text { Nuclear Materials } \\ 23 & \text { Warhead Electrical Components and Technologies } \\ 28 & \text { Non-Nuclear Materials } \\ 29 & \text { Nuclear Counter-Terrorism Technology } \\ 30 & \text { Facilities } \\ 31 & \text { Nuclear Weapons Engineering } \\ 32 & \text { Nuclear Warhead Physics } \\ 34 & \text { Computational Technology } \\ 36 & \text { Aircraft, Missile and Space System Hardening } \\ 37 & \text { Laboratory Plasma Physics } \\ 39 & \text { Manufacturing Practices } \\ 41 & \text { Nuclear Warhead Accident Response } \\ 42 & \text { Nuclear Weapon Code Development } \\ 43 & \text { Nuclear Weapon Environment and Damage Effects } \\ \# \text { unknown } & \text { Methodologies for Nuclear Weapon Safety Assurance }\end{array}$

Source: House of Commons, Hansard, 22 February 2005, column 601.

\section{Nuclear warhead design and construction}

The 1958 MDA created the Joint Atomic Information Exchange Group and dozens of Joint Working Groups, or JOW OGs (see Table 1). Documents obtained by the U.S. Natural Resources Defense Council show that the United States supplied the designs of many weapons to the British. The U.K.'s national archives on the JOWOGs, even from 1960, are still sealed. The titles of some documents from that era show that the United Kingdom was briefed on the use of beryllium, plutonium, and uranium and the Americans were presented with the results of British experiments using U.S.-supplied bomb parts. U.S. officials also benefit from the exchanges because of the innovative and skillful approach of their resource-starved British counterparts.

In the early 1960s, public concern over the nuclear arms race focused on the test explosions of nuclear weapons in the atmosphere and the accumulation of radiation in milk. After the 1963 U.K./U.S./U.S.S.R. agreement of the atmospheric test ban, the United Kingdom was only able to carry out test explosions jointly with the United States at the underground test site in Nevada. Then, in 1996, President Clinton's support for a test ban forced John Major's government to follow suit and sign the Comprehensive Test Ban Treaty. The last U.S./U.K. tests at Nevada were code-named Barnwell (1989), Houston (1990), and Bristol (1991).

For many years, the JOWOGs were secret and were only obliquely referred to in the open literature. Thus, two of the main British academic studies on Anglo-American defense relations and nuclear weapons make no more than a passing reference to them. ${ }^{13}$ It was only through the work of the Natural Resources Defense Council in Washington, D.C., Greenpeace U.K., and BASIC, that the JOW OGs were first discussed in public. Subsequent activity by MPs such as Frank Cook and Alan Simpson led to the British government providing occasional lists of the JOWOGs to Parliament. ${ }^{14}$

The principal role of the JOWOGs is to assist the British in producing nuclear warheads. Since the mid-1960s, the United Kingdom has deployed four types of nuclear weapon, some with variants. These are the Royal Air Force WE-177, and three types that were produced in succession for Royal Navy Strategic Ballistic Missile Submarines. These three types are Polaris, Chevaline/Polaris, and Trident Only Trident is in service today.

The RAF and Royal Navy used the WE-177 free-fall bomb with three versions for different military tasks. However, the British only conducted three nuclear tests in the period when the weapon was developed, making a British-only design most unlikely. Quite how the warhead was designed remains a secret. However, an analysis by the Natural Resources Defense Council (NRDC) concludes that the WE-177 was probably based on U.S. designs (the Mark 57 and B61). A declassified U.S. document from 1960 obtained by the NRDC says that the U.K. "plans to produce several versions of the Mark 57."15

The United States supplied the design for Polaris (the W-58). In heated exchanges in the House of Commons between the Prime Minister Lord Home and Harold Wilson, Home confusingly said that the Polaris warhead was probably "both" the U.S. design and a British design of the same size. ${ }^{16}$ Further evidence that the Polaris warhead was not a British design was that Home saw no need to test it at all, although Harold Wilson did get U.S. permission to conduct one.

In the early 1970 s, the United States stopped the key part of the JOWOG cooperation when the Labor government said that it would not have a new nuclear weapon. There was consternation at Aldermaston - a manufacturing facility where the Trident warheads are made - at the loss of access to U.S. bombmakers. U.S. support resumed when, under the premierships of Edward Heath and Harold Wilson, a secret program to put a new warhead on Polaris was begun. This program, known as Chevaline or "Super-Antelope" in Britain, was based on Lockheed's U.S. Antelope project. Technically, its function was to defeat Soviet missile defenses, but politically its function was to keep U.S. nuclear support. ${ }^{17}$

In 1979, Margaret Thatcher's new Defense Secretary, Francis Pym, announced Chevaline in Parliament. This caused much infighting in the Labor Party, whose 
members had known nothing of this program, which was in violation of the decisions of the party conference. ${ }^{18}$

The independence of the warheads was a key defense that supporters of the independent deterrent used against the charge that the system was U.S.-dependent. However, documents available in U.S. presidential archives prove that the Nixon, Ford, Reagan, and G.H.W. Bush administrations all authorized the supply of nuclear weapons parts as necessary to the United Kingdom. ${ }^{19}$

Missiles

Forty years ago, Harold Macmillan had to deal with the fact that not only could the government not afford independent bombs, it could not afford independent missiles either. His government first sought a U.S. air-launched missile, Skybolt, and, when this was cancelled, was offered the U.S. Navy's Polaris missile.

The December 1962 Nassau agreement to provide the United Kingdom with Polaris provided the U.K. with missiles, submarine, and reactor technology. President Kennedy offered a similar deal to the French President Charles de Gaulle. ${ }^{20}$ In January 1963, De Gaulle made a speech rejecting the U.S. offer of Polaris to France and vetoing British membership of the Common Market on the grounds that the British had now come under U.S. control.

Macmillan's Permanent Secretary, Sir Robert Scott, recorded that the decision has "put us in America's pocket for a decade." The commander of the Royal Air Force nuclear bomber force wrote privately that the deal had been done to sustain the "myth" of an independent force. ${ }^{21}$

The two key agreements on U.S.-support made by Macmillan (the MDA and Polaris) were made because Britain was too weak to act independently. This underlying fact has meant that no government has sought to change the framework of agreements established by Macmillan; rather, they have been anxious to ensure that the United States keeps renewing them.

The Labor government of Harold Wilson came to power in 1964. Its manifesto said that Polaris "will not be independent and it will not be British and it will not deter." Nevertheless, with most of the money committed, the Wilson Cabinet, with the support of Parliament, continued the program, although even in retirement Wilson said: "I never believed that we had a really independent deterrent." 22

\section{Trident and beyond}

U.S. management and technology, including nuclear materials, is involved throughout the Trident weapons system and continues the process begun in the 1940s (see Table 2). According to the National Audit Office report of 1987:

The U.S. will supply the missiles and associated strategic weapon systems

Table 2: U.K. Trident dependence on the U.S.

Trident component Nature of U.S. dependence

- Warhead design

- Warhead nuclear components

- Warhead nuclear factory

- Warhead non-nuclear parts

- Firing system

- D-5 Missiles

\section{- Missile guidance}

- Submarines

- Aldermaston

- Maintenance base

Notes:

* DSCR6 (1993, HC 549)

** See, for example, Table 1 and the provisions of the Mutual Defense Agreement.

*** In-service support and refurbishment for Britain's nuclear submarines is provided by the Devonport Management (DML) group, 51 percent owned by Halliburton (see www.devonport.co.uk).

equipment, certain warhead-related components and services, and missile preparation and refurbishment services: the remainder of the programme will be carried out by the U.K. ${ }^{23}$

A former British official engaged in the acquisition of Trident explained to the author that the Royal Navy assessment in the 1980s was that the system would remain functional for eighteen months if the United States withdrew support. Since then, U.S. corporations have extended their management of the program, probably reducing this period. ${ }^{24}$ 
The supply of Trident commanded a political price from the government in London. In his seminal study "Nuclear Weapons: Who's in Charge?" Hugh Miall records comments from two British officials on the state of U.S. influence in the mid1980s: "Sir Frank Cooper, the Permanent Under Secretary of Defence, said, 'if you ask me whether the Americans have an undue degree of influence over British defence policy I would have to say yes'." And, also according to Miall, Clive Ponting, a former Ministry of Defense official said:

Client state is putting it a bit strongly but there are very clear signs I think that it's not far short of that ... They clearly do have an undue degree of influence because when the chips are down we side with the Americans because we think the American nuclear and intelligence material is so important to us that we are prepared to pay that price to keep the material flowing. ${ }^{25}$

One area where the price was paid was in support for the U.S. Star Wars program, which was strongly opposed by Foreign Office and Ministry of Defense officials. Initial doubts were expressed by the Foreign Secretary, Geoffrey Howe, only for the Prime Minister to bring the United Kingdom into line with Washington, a pattern familiar in recent years

\section{The Trident warheads}

In June 1991, President George H.W. Bush issued National Security Directive 61, now partly declassified. He ordered that the Department of Energy "shall produce additional nuclear weapons parts as necessary for transfer to the United Kingdom pursuant to the Agreement of Cooperation" for a period up until 1997.

According to a U.K. National Audit Office statement on warhead development and production, "most of the development and production expenditure is incurred in the U.S." These costs included the cost of testing the weapons in Nevada: "[Regarding] special materials ... in 1982 Ministers decided ... that a substantial proportion [of the explosive nuclear material] should be purchased in the U.K. [from British Nuclear Fuels plc]." ${ }^{26}$ Therefore, the remaining portion of the nuclear materials in the warheads comes from the United States. Baylis describes how, in the mid-1980s, Britain was "dependent for "vital materials' for warhead production." 27 The ostensibly British warhead was test-fired at the U.S. underground test-site in Nevada.

The Aldermaston A-90 manufacturing facility, where the Trident warheads are made, "appears to be a direct copy of the Plutonium Processing Facility (TA-55) at Los Alamos." 28

The United States provided Britain with details of its Trident nuclear warhead design and sells Britain its cone-shaped casing. ${ }^{29}$ The U.S. Sandia plant "also designs the arming-fusing-firing mechanisms for all of the United Kingdom's nuclear weapons." 30

\section{Trident missile and submarine system}

The British version of the U.S. Trident system consists of four submarines built at Barrow in Furness, each fitted with sixteen missiles. The submarines can sail to any part of the world's oceans. Powered by nuclear reactors they can stay underwater, undetected, for months at a time.

The submarines must collect the missiles from a U.S. port in Georgia on the Atlantic coast under a lease-purchase arrangement. The extra missiles for Trident's predecessor, Polaris, were British-owned and stored at a base in Scotland, making Britain less dependent on the United States. Denis Healey heaped derision on the arrangement:

Under the rent-a-rocket agreement we have to swap these Moss Bros missiles every seven or eight years for other missiles in the American stockpile ... [there are] some serious political disadvantages, which can be summed up as a period of prolonged and humiliating dependence on the United States. ${ }^{31}$

The Trident D-5 missiles are occasionally test-fired from the submarines using a U.S. naval facility.

President Bush's support for U.K. WMD

A key objective for the Blair government during 2003 was to ensure the renewal in 2004 of the Mutual Defense Agreement (MDA) with minor amendment that permits the United States to share nuclear weapons technology with Britain. The present Bush administration prides itself on its tough pursuit of U.S. interests. One can logically deduce that the Bush administration would not have renewed the MDA without being certain that the United Kingdom will continue to provide reliable support.

In a formal letter to his officials endorsing the renewal, President Bush said that the United Kingdom is

making substantial and material contributions to the mutual defense and security The proposed Amendment will permit cooperation that will further improve our mutual defense posture and support our interests under the North Atlantic Treaty Organization (June 14, 2004).

\section{He explained to Congress that that agreement will continue to}

permit the transfer of nonnuclear parts, source, byproduct, special nuclear materials, and other material and technology for nuclear weapons and military 
reactors ... In the light of our previous close cooperation and the fact that the United Kingdom has committed its nuclear forces to the North Atlantic Treaty Organization, I have concluded that it is in our interest to continue to assist them in maintaining a credible nuclear force. ${ }^{32}$

For George Bush, his decision appears to makes Britain's nuclear force credible. Would he do so free of charge? U.S. support does not, in fact, make the idea of British independence more credible - quite the opposite.

Had the United Kingdom not gone to war with the United States in Iraq, neither President Bush nor the Congress are likely to have agreed that cooperation was close, especially in the climate of "you are either with us or against us" that has prevailed since 11 September 2001.

However, it is reasonable to assume that nuclear weapons technology is supplied with a quid pro quo, although this is not publicly acknowledged.

\section{Firing Trident}

This section discusses whether Britain could engage in a nuclear war independently of Washington. Sir Michael Quinlan has conceded that the United Kingdom has no independence of procurement of nuclear weapons but nonetheless argues that this does not matter since the United Kingdom could fire the weapons independently. He also concedes that over time (unspecified) the United States could cause the United Kingdom to cease to be a nuclear power. ${ }^{33} \mathrm{He}$ further said that the United Kingdom's decision to choose independence of operation meant that "in the last resort, when the chips are down and we are scared, worried to the extreme, we can press the button and launch the missiles whether the Americans say so or not." And he argued that the decision to fire is an independent, sovereign decision: the United States "can neither dictate that the [U.K.'s] force be used if HMG does not so wish, nor [can it] apply any veto-legal or physical-if HMG were to decide upon [its] use." ${ }^{34}$

Dr. John Reid, then the U.K. Defense Secretary, explained that "the United Kingdom's independent nuclear deterrent can be targeted and used without the approval of any other country." ${ }^{35}$ However, if one asks "can it be used if the United States disapproves?," we can see from the previous analysis that this is most unlikely. Half a century ago, at Suez, the British had to abandon a military operation under economic pressure from Washington. In any crisis that developed over a period of time where the United States and the United Kingdom were at odds, the United States would have economic, technical, and military means to prevent the United Kingdom using its system, and the longer the period of disagreement lasted the greater is the United States' ability to make the system it supplied inoperable. Although considerable secrecy surrounds this issue, past some public statements from earlier years and more recent off-the record statements undermine the idea that the United Kingdom even operates its nuclear weapons independently.
Even in the days before Polaris, it was obvious that the United States did not regard the United Kingdom as an independent nuclear force. In 1962, Robert McNamara, the U.S. Defense Secretary, spoke out about the "dangerous" contribution of small nuclear powers. This created headlines in Britain and was seen as an attack on the U.K. nuclear force. McNamara and his advisors sought to soothe the British press by explaining that they were only talking about the French, since the British "did not operate independently." 36 Air Vice Marshall Stuart Menaul wrote in 1980 that

Britain no longer has an independent nuclear deterrent ... strategic considerations as far as Britain is concerned are no longer relevant ... it could only be used after authority for the use of nuclear weapons had been conveyed from the President of the United States to SACEUR [the U.S. general at NATO]. ${ }^{37}$

Both governments state that the United Kingdom's weapons are assigned to NATO What does this mean in practice? According to sources familiar with the process, the United States is aware, through the NATO command structure and the U.S. Strategic Command (STRATCOM), of the location and deployments of Trident submarines U.S. communications and satellite facilities are normally used for keeping in touch with the submarines and for targeting the missiles.

The command chain from the British Prime Minister to the submarine captains does not involve the Americans. Yet the United Kingdom makes use of U.S. satellites to aim Trident. Former U.K. Trident launch control officers have said that it would be very difficult to fire the missiles without the use of the satellites. ${ }^{38}$ John Ainslie has provided details of British reliance on U.S. computer software, satellite-generated targeting information, and related systems that would permit the United States to interfere with a British Trident launch. ${ }^{39}$

Sir Michael Quinlan derided the argument that the United States could prevent the United Kingdom firing Trident in extremis, but in a world at nuclear war it is simply naive to expect that the United States would not use all means necessary to enforce its will. Day-to-day, the United States has a general idea where the U.K. submarines are, since they are assigned to NATO, and it has the physical ability to interrupt U.K communications by jamming or kinetic action. Over any longer period it becomes even easier for the United Kingdom to be brought under control.

\section{A state of denial}

In the 2006 House of Commons debate on the Trident none of the official government, opposition, and Liberal Democrat speakers discussed the importance of the dependence of the United Kingdom on the United States for the supply of nuclear weapons. This is startling since, in an unprecedented investigation, the Defense Select Committee did examine the issue and highlighted it in its report, in the summary of the oral evidence, and in the ordering of the written evidence at its first hearing on the 
subject. Moreover, it later returned to the matter.

This article has demonstrated that since the early 1940 s economic constraints have driven the United Kingdom to ever greater dependence upon the United States, resulting in reduced rather than increased national independence in direct opposition to the stated purpose of the program.

The United Kingdom does not have, and never has had, fully independent nuclear capability. The United Kingdom does have a nuclear weapons program, but it is and always has been dependent on U.S. technology and supplies. Even between 1946 and 1958 , U.S. information acquired during the war was the basis of the program and the United States provided secret support. Successive British governments have decided that the United Kingdom would not make the investment that France did over the years in developing its force de frappe. As technology has become more expensive and sophisticated, so the U.K. contribution to U.K.-operated weapons systems has been reduced. For example, when the United States moved from Trident I to Trident II, the United Kingdom decided it could not afford to purchase the missiles outright and store them in the U.K., but opted for their lease-purchase.

It is occasionally argued that the United Kingdom could go it alone as France or China have done. Successive U.K. governments have decided since the 1940s that the country does not have the resources to do this. A break with the United States would likely result in the total withdrawal of U.S. technology, expertise, machine tools, and so forth. The lead time involved in the creation of an independent capability to produce warheads and delivery systems would be many years in the making even were the funds to be found. An independent force is not an option in the short or medium-term, regardless of the funding, since the United Kingdom simply does not have an adequate nuclear defense-industrial base to build-on now. Continuous dependence has meant that in contrast to France, the United Kingdom does not have the ability to produce ballistic or cruise missiles, nuclear submarines, nuclear weapons production facilities, and the full range of nuclear explosive materials and associated electronics.

The present government will not say how much of the spending on U.K. Atomic Weapons Establishment goes to U.S. corporations, and we have to rely on the data given at the time of Trident when the National Audit Office put the figure at $2 / 3 \mathrm{rds}$ of the total United Kingdom expenditure on the Trident warhead. The total lifecycle cost of a Trident replacement up to 2042 has been put at $£ 74$ billion. But that the United Kingdom is spending money on activity at a factory located in the U.K. is no signifier of independence.

In general, the British public believes that the country is protected by an independent nuclear deterrent. No government wishes to admit to the weakness that dependence implies.

In return for U.S. support for the U.K. nuclear weapons program, the United Kingdom is compelled to support, broadly, U.S. international policy. Today though, with widespread concern over the long-term direction of U.S. policy it is essential that the public understand the underlying connection between the special nuclear relationship and the special political relationship.

In an exchange of letters, President Bush and then-Prime Minister Blair confirmed that the United Kingdom will continue to rely on the United States for nuclear weapons up to 2029 and beyond. This course of action will not supply

Britain with a weapon it could use if it ever stood alone, as in 1940. The unfortunate reality for the British people is that, unknown to them, they have a nuclear weapon that does not do what it says on the can.

There are a number of lessons to be drawn from this conclusion. First, the British people may wish to continue a dependent relationship with Washington, but they should do so with open eyes and not believe that they can ever have a government that acts with strategic independence so long as Aldermaston is run by Lockheed.

Second, people outside the United Kingdom should be aware that the nuclear special relationship does indeed produce the oft-ridiculed lap-dog status for the United Kingdom

Third, full-scale nuclear proliferation is not that easy given that even the United Kingdom, until recently the world's fourth largest economy, found the stakes too high to play the game. Other states, China included, have very small forces of limited regional capacity.

Fourth, British supporters of a Trident successor do so on the basis that it is independent. Opponents of the system too often accept this, or at least mix it into a broader range of arguments, whereas, the independence issue is the foundation of the entire project, and by focusing their limited energy on this one issue rather than on a range of topics, their critique has a far greater chance of success.

Fifth, and finally, the extent of the support for nuclear warhead production amounts to an "indirect" transfer of nuclear weapons, a practice that under Article I of the Non-Proliferation Treaty (NPT), the United States and the United Kingdom are legally prohibited from engaging in. Those concerned to enforce international law with respect to nuclear weapons may find that the matter as laid out here provides a case for using Article I of the NPT at least as much as the oft-cited Article VI.

Notes

Dan Plesch is Director of the Center for International Studies and Diplomacy at the School of Oriental and African Studies, University of London, U.K. He may be reached atdp27@soas.ac.uk. This article is an excerpt from and elaboration on "The 
Future of Britain's WMD," which I wrote for the Foreign Policy Center in 2005 and was first published in 2006 by The Foreign Policy Center, 49 Chalton Street, London NW 1 1HY, United Kingdom.

1. DSCR8 (2005-6); HC 986 summary and relevant sections; see also HC 835 written evidence.

2. Remarks by Julian Lewis, MP, at the Royal United Services Institute, 6 July 2005.

3. Bellamy (2005).

4. Groom (1974, chapter 1).

5. Gowing (1974, p. 3)

6. Paul (2000)

7. Paul (2000).

8. Groom (1974, p. 31).

9. Hennessy (2002, p. 31).

10. Gowing (1974).

11. FCSC (1958, quoted in Baylis, 1984).

12. The Times (29 April 2004).

13. Simpson (1986); Baylis (1997).

14. Alan Simpson, MP (House of Commons, Hansard, 15 December 1994, c. 1222).

15. Peden (1991).

16. House of Commons, Hansard (12 May 1964, c. 222-223).

17. Spinardi (1997).

18. House of Commons (Hansard, 15 February 1989, c 383).

19. Plesch (2006).
20. “On This Day,” BBC News Archive, 21 December 1962 http://news.bbc.co.uk/ onthisday/hi/dates/stories/december/21/newsid_3815000/3815251.stm [accessed 28 September 2007].

21. Cited in Clark (1994, pp. 413, 418).

22. See Hennessy (2002, pp. $70 \mathrm{ff})$.

23. NAO (1987, para. 1.1).

24. A former official speaking on condition of anonymity, 2006.

25. Miall (1987, p. 77).

26. NAO (1987, app. 4, pars 1-4); DSCR3 (1987, p. 22).

27. Baylis (1997, p. 195).

28. Norris (1994, pp. 72 ff)

29. JAIEG (1983).

30. D. Kramer, cited in Peden (1999).

31. See Dumbrell (2000, p. 145).

32. Both quotes from Bush (2004).

33. Quinlan (2006).

34. DSCR8 (2005-06; HC 986 and 835).

35. House of Commons (Hansard, 31 October 2005, c. 720W).

36. Clark (1994, pp. 334-337).

37. Menaul (1980, pp. 7, 172).

38. A former official speaking on condition of anonymity. http://www.publications parliament.uk/pa/cm200607/cmselect/cmdfence/225/22514.htm [accessed September 2007] 
(C) www.epsjournal.org.uk - Vol. 3, No. 1 (2008)

39. Ainslie (2005). Also see http://www.basicint.org/nuclear/beyondtrident/cost.pdf [accessed Nov 7 2007].

\section{References}

Ainslie, J. 2005. "The Future of the British Bomb." Posted at http://www.comeclean. org.uk/articles.php?articleID=132 [accessed 29 September 2007].

Arnold, L. 2001. Britain and the H-Bomb. London: Palgrave Macmillan.

Baylis, J. 1984. Anglo-American Defense Relations, 1939-1984. 2nd ed. London: Macmillan.

Baylis, J. 1997. Anglo American Relations since 1939. Manchester: Manchester University Press.

Bellamy, C. 2005. "British Nuclear Forces, the decision that dare not speak its name", The World Today, Vol. 65, No.1 (May).

Bush, G.W. 2004. "Memorandum for the Secretary of Defense and the Secretary of Energy." 14 June 2004. http://www.whitehouse.gov/news/releases/2004/06/ 20040614-15.html [accessed 29 November 2007].

Clark, I. 1994. Nuclear Diplomacy and the Special Relationship: Britain's Deterrent and America, 1957-1962. Oxford: Clarendon Press.

[DSCR8] Defence Select Committee Eighth Report. 2005-6. "The Future of the UK's Strategic Nuclear Deterrent." House of Commons session 2005-2006.

[DSCR6] Defence Select Committee Sixth Report. 1993. "The Progress of the Trident Programme." 16 June 1993.

[DSCR3] Defence Select Committee Third Report. 1987. "Progress of the Trident Programme." HC 1987-1988.

Dumbrell, J. 2000. A Special Relationship. London: Palgrave Macmillan.

[FCSC] Foreign Office Steering Committee. 1958. "Planning Paper on Interdependence." (58)8, 27 January 1958, PRO FO371/132330.

Gowing, M. 1974. Independence and Deterrence. Vol. 1. London: Macmillan.

Groom, A.J.R. 1974. British Thinking about Nuclear Weapons. London: Pinter.

Hennessy, P. 2002. The Secret State. London: Penguin/ Allen Lane.

[JAIEG] Joint Atomic Information Exchange Group. 1983. "Annual Historical Summary [U]." HQ Defence Nuclear Agency (1 October 1982-30 September 1983).

Menaul, S. 1980. Countdown. London: Hale.

Miall, H. 1987. Oxford Research Group. London: Macmillan.

[NAO] National Audit Office. 1987. "Ministry of Defence and Property Services Agency: Control and Management of the Trident Programme." ISBN 0102027889. London: National Audit Office.

Norris R.S., et al. 1994. Nuclear Weapons Databook: British, French and Chinese Nuclear Weapons. Vol. 5. Boulder, CO: Westview.

Paul, S. 2000. Nuclear Rivals: Anglo-American Atomic Relations,
1941-1952.Columbus, OH: Ohio State University Press.

Peden, W. 1991. "Safety of British Nuclear Weapon Designs." British American Security Information Council.

Peden, W. 1999. "The Next Chevaline Scandal.” London: Campaign for Nuclear Disarmament.

Plesch, D. 2006. “Trident, We've Been Conned Again.” New Statesman (27 March) Quinlan, M. 2006. "The Future of United Kingdom Nuclear Weapons: Shaping the Debate." International Affairs, Vol. 82, No. 4, pp. 627-637.

Simpson, J. 1986. The Independent Nuclear State. London: MacMillan.

Spinardi, G. 1997. "Aldermaston and British Nuclear Weapons Development: Testing the 'Zuckerman Thesis'." Social Studies of Science, Vol 27, pp. 547-582. 